\title{
Seven Faces of "The Peril"
}

\author{
James Bullard
}

In this paper the author discusses the possibility that the U.S. economy may become enmeshed in a Japanese-style deflationary outcome within the next several years. To frame the discussion, the author relies on an analysis that emphasizes two possible long-run steady states for the economy: one that is consistent with monetary policy as it has typically been implemented in the United States in recent years and one that is consistent with the low nominal interest rate, deflationary regime observed in Japan during the same period. The data considered seem to be quite consistent with the two steady-state possibilities. The author describes and critiques seven stories that are told in monetary policy circles regarding this analysis and emphasizes two main conclusions: (i) The Federal Open Market Committee's "extended period" language may be increasing the probability of a Japanese-style outcome for the United States and (ii), on balance, the U.S. quantitative easing program offers the best tool to avoid such an outcome.

(JEL E4, E5)

This article first appeared in the September/October 2010 issue of Review.

Federal Reserve Bank of St. Louis Review, November/December 2013, 95(6), pp. 613-28.

\section{THE PERIL}

I

n 2001, three academic economists published a paper entitled "The Perils of Taylor Rules." 1

The paper has vexed policymakers and academics alike, as it identified an important and

very practical problem - a peril-facing monetary policymakers, but provided little in the way of simple resolution. The analysis appears to apply equally well to a variety of macroeconomic frameworks, not just to those in one particular camp or another, so that the peril result has great generality. And, most worrisome, current monetary policies in the United States (and possibly Europe as well) appear to be poised to head straight toward the problematic outcome described in the paper.

James Bullard is president and CEO of the Federal Reserve Bank of St. Louis. Any views expressed are his own and do not necessarily reflect the views of other Federal Open Market Committee members. The author benefited from review and comments by Richard Anderson, David Andolfatto, Costas Azariadis, Jess Benhabib, Cletus Coughlin, George Evans, William Gavin, Seppo Honkapohja, Narayana Kocherlakota, Michael McCracken, Christopher Neely, Michael Owyang, Adrian Peralta-Alva, Robert Rasche, Daniel Thornton, and David Wheelock. Marcela M. Williams provided outstanding research assistance.

This article has been reformatted since its original publication in Review: Bullard, James. "Seven Faces of 'The Peril'." Federal Reserve Bank of St. Louis Review, September/October 2010, 92(5), pp. 339-52; http://research.stlouisfed.org/publications/review/10/09/Bullard.pdf.

( ) 2013, The Federal Reserve Bank of St. Louis. The views expressed in this article are those of the author(s) and do not necessarily reflect the views of the Federal Reserve System, the Board of Governors, or the regional Federal Reserve Banks. Articles may be reprinted, reproduced, published, distributed, displayed, and transmitted in their entirety if copyright notice, author name(s), and full citation are included. Abstracts, synopses, and other derivative works may be made only with prior written permission of the Federal Reserve Bank of St. Louis. 
Figure 1

Interest Rates and Inflation in Japan and the U.S.



NOTE: Short-term nominal interest rates and core inflation rates in Japan and the United States, 2002-10.

SOURCE: Data from the Organisation for Economic Co-operation and Development.

The authors of the 2001 paper-Jess Benhabib at New York University and Stephanie Schmitt-Grohé and Martín Uribe both now at Columbia University_studied abstract economies in which the monetary policymaker follows an active Taylor-type monetary policy rule-that is, the policymaker changes nominal interest rates more than one for one when inflation deviates from a given target. Active Taylor-type rules are so commonplace in present-day monetary policy discussions that they have ceased to be controversial. Benhabib, Schmitt-Grohé, and Uribe also emphasized the zero bound on nominal interest rates. They suggested that the combination of an active Taylor-type rule and a zero bound on nominal interest rates necessarily creates a new long-run outcome for the economy. This new long-run outcome can involve deflation and a very low level of nominal interest rates. Worse, there is presently an important economy that appears to be stuck in exactly this situation: Japan.

To see what these authors were up to, consider Figure 1. This is a plot of nominal interest rates and inflation for both the United States and Japan during the period from January 2002 through May 2010. The frequency is monthly. The Japanese data are the circles in the figure, and the U.S. data are the squares. The short-term nominal interest rate is on the vertical axis, and the inflation rate is on the horizontal axis. To maintain as much international comparability as possible, all data are from the Organisation for Economic Co-operation and Development (OECD) main economic indicators (MEI). The short-term nominal interest rate is taken to be the policy rate in both countries - the overnight call rate in Japan and the federal funds rate in 
the United States. Inflation in the figure is the core consumer price index inflation rate measured from one year earlier in both countries. The data in the figure never mix during this time period: The U.S. data always lie to the northeast, and the Japanese data always lie to the southwest. This will be an essential mystery of the story.

Benhabib, Schmitt-Grohé, and Uribe (2001) wrote about the two lines in the figure. The dashed line represents the famous Fisher relation for safe assets-the proposition that a nominal interest rate has a real component plus an expected inflation component. I have taken the real component (also the rate of time preference in the original analysis by Benhabib, Schmitt-Grohé, and Uribe) to be fixed and equal to 50 basis points in the figure. $\stackrel{2}{\text { Practically speaking, any macro- }}$ economic model of monetary phenomena will have a Fisher relation as a part of the analysis, and so this line is hardly controversial. The solid line in the figure represents a Taylor-type policy rule: It describes how the short-term nominal interest rate is adjusted by policymakers in response to current inflation. In the right half of the figure, when inflation is above target, the policy rate is increased, but more than one for one with the deviation of inflation from target. And when inflation is below target, the policy rate is lowered, again more than one for one. When the line describing the Taylor-type policy rule crosses the Fisher relation, we say there is a steady state at which the policymaker no longer wishes to raise or lower the policy rate, and, simultaneously, the private sector expects the current rate of inflation to prevail in the future. It is an equilibrium in the sense that, if there are no further shocks to the economy, nothing will change with respect to inflation or the nominal interest rate. In the figure, this occurs at an inflation rate of 2.3 percent and a nominal interest rate of 2.8 percent (denoted by an arrow on the right side of the figure). This is sometimes called the "targeted" steady state. $\underline{\underline{3}}$

The "active" policy rule-the fact that nominal interest rates move more than one for one with inflation deviations in the right half of the figure-is supposed to keep inflation near the target. It also means that the line describing the Taylor-type policy rule is steeper than the line describing the Fisher relation in the neighborhood of the targeted inflation rate. It cuts the Fisher relation from below. Taken at face value, the Taylor-type policy rule has been fairly successful for the United States: Inflation (by this measure) has been neither above 3 percent nor, until very recently, below 1 percent during the January 2002-May 2010 period.

None of this so far is really the story told by Benhabib, Schmitt-Grohé, and Uribe. On the right-hand side of the figure, short-term nominal interest rates are adjusted up and down to keep inflation low and stable. It's all very conventional. The point of the analysis by Benhabib, SchmittGrohé, and Uribe is to think more carefully about what these seemingly innocuous assumptionsthe Fisher relation, the active Taylor-type rule, the zero bound on nominal interest rates-really imply as we move to the left in the figure, far away from the targeted steady-state equilibrium. And, what these building blocks imply is only one thing: The two lines cross again, creating a second steady state. In the figure, this second steady state occurs at an inflation rate of -50 basis points and an extremely low short-term nominal interest rate of about one-tenth of a basis point (see the arrow on the left side of the figure). $\underline{4}$ The Japanese inflation data are all within about 100 basis points of this steady state, between -150 basis points and 50 basis points. That's about the same distance from low to high as the U.S. inflation data. But for the nominal interest rate, most of the Japanese observations are clustered between 0 and 50 basis points. The policy rate 
cannot be lowered below zero, and there is no reason to increase the policy rate since-well, inflation is already "too low." This logic seems to have kept Japan locked into the low nominal interest rate steady state. Benhabib, Schmitt-Grohé, and Uribe sometimes call this the "unintended" steady state. $\frac{5}{}$

At the unintended steady state, policy is no longer active: It has instead switched to being passive. The policy line crosses the Fisher relation from above. When inflation decreases, the policy rate is not lowered more than one for one because of the zero lower bound. And when inflation increases, the policy rate is not increased more than one for one because, in this region of the diagram, inflation is well below target. Fluctuations in inflation are in fact not met with much of a policy response at all in the neighborhood of the unintended steady state. At this steady state, the private sector has come to expect the rate of deflation consistent with the Fisher relation accompanied by very little policy response; thus, nothing changes with respect to nominal interest rates or inflation. Where does policy transition from being active to being passive? This occurs when the slope of the nonlinear Taylor-type rule is exactly 1 , which is at an inflation rate of about 1.56 percent in Figure 1.

Again, the data in this figure do not mix at all-it's boxes on the right and circles on the left. But the most recent observation for the United States, the solid box labeled "May 2010," is about as close as the United States has been in recent times to the low nominal interest rate steady state. It is below the rate at which policy turns passive in the diagram. In addition, the Federal Open Market Committee (FOMC) has pledged to keep the policy rate low for an "extended period." This pledge is meant to push inflation back toward target-certainly higher than where it is today-thus moving to the right in the figure. Still, as the figure makes clear, pledging to keep the policy rate near zero for such a long time would also be consistent with the low nominal interest rate steady state, in which inflation does not return to target but instead both actual and expected inflation turn negative and remain there. Furthermore, we have an example of an important economy that appears to be in just this situation.

A key problem in the figure is that the monetary policymaker uses only nominal interest rate adjustment to implement policy. This is the meaning of the nonlinear Taylor-type policy rule continuing far to the left in the diagram. The policymaker is completely committed to interest rate adjustment as the main tool of monetary policy, even long after it ceases to make sense (long after policy becomes passive), creating a second steady state for the economy. Many of the responses described below attempt to remedy the situation by recommending a switch to some other policy when inflation is far below target. The regime switch required must be sharp and credible-policymakers have to commit to the new policy and the private sector has to believe the policymakers. Unfortunately, in actual policy discussions nothing of this sort seems to be happening. Both policymakers and private sector players continue to communicate in terms of interest rate adjustment as the main tool for the implementation of monetary policy. This is increasing the risk of a Japanese-style outcome for the United States.

My view is that the 2001 analysis by Benhabib, Schmitt-Grohé, and Uribe is an important one for current policy, that it has garnered insufficient attention in the policy debate, and that it is indeed closely related to the current "extended period" pledge of the FOMC. Below I relate and critique seven stories-both formal ones and informal ones-that I have encountered con- 
Centennial Issue

\section{Figure 2}

\section{Denial}

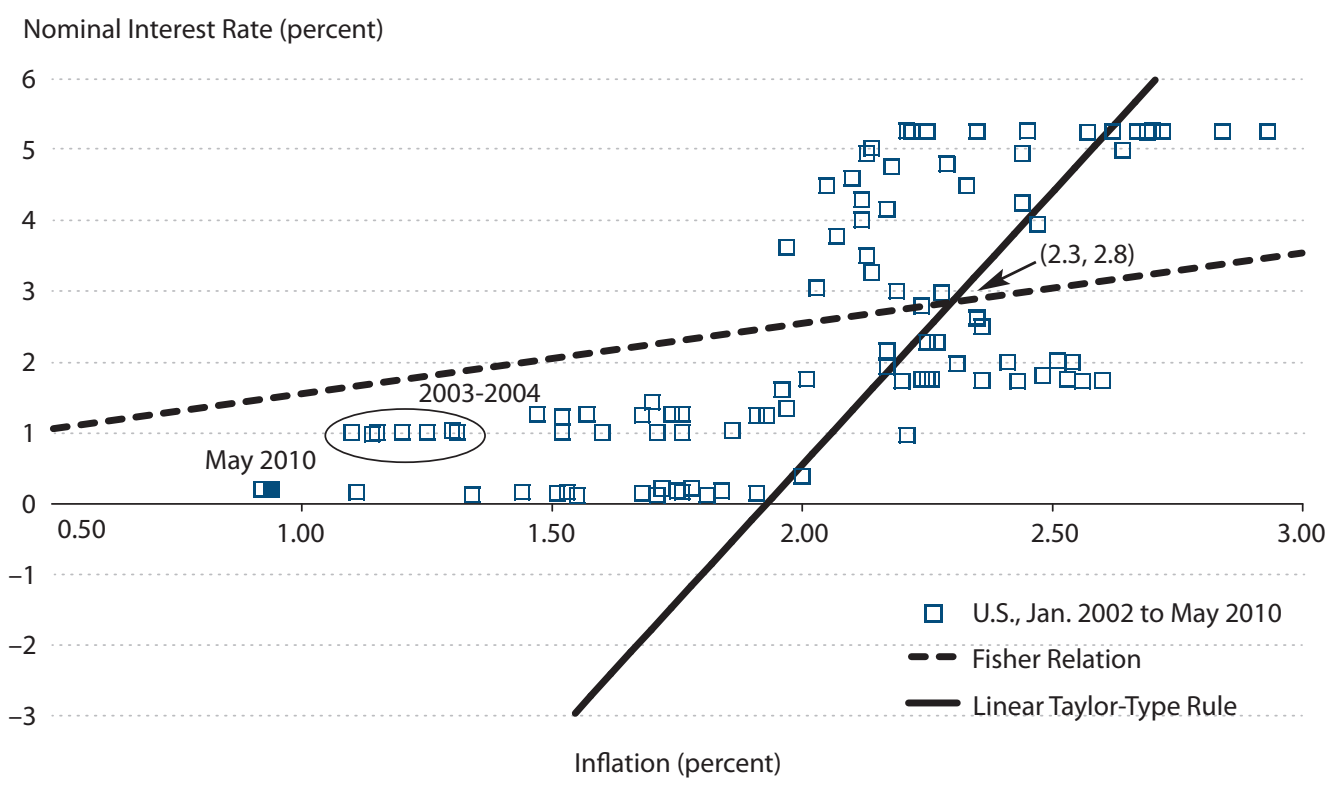

cerning this analysis. The fact that there are seven "faces" shows just how fragmented the economics profession is on this critical issue. These stories range from reasons not to worry about the implications of Figure 1, through ways to adjust nominal interest rates to avoid the implications of Figure 1, and on to the uses of unconventional policies as a tool to avoid "the peril."

I conclude that promises to keep the policy rate near zero may be increasing the risk of falling into the unintended steady state of Figure 1 and that an appropriate quantitative easing policy offers the best hope for avoiding such an outcome.

\section{SEVEN FACES}

\section{Denial}

I think it is fair to say that, for many who have been involved in central banking over the past two or three decades, it is difficult to think of Japan and the United States in the same game, as Figure 1 suggests. For many, the situation in Japan since the 1990s has been a curiosum, an odd outcome that might be chalked up to particularly Byzantine Japanese politics, the lack of an inflation target for the Bank of Japan (BOJ), a certain lack of political independence for the BOJ, or some other factor specific to the Land of the Rising Sun. The idea that U.S. policymakers should worry about the nonlinearity of the Taylor-type rule and its implications is sometimes viewed as an amusing bit of theory without real ramifications. Linear models tell you everything you need to know. And so, from this denial point of view, we can stick with our linear models and ignore the data from Japan (Figure 2). 
In Figure 2, the targeted steady state remains at an inflation rate of 2.3 percent, but the Taylor-type rule is now linear. The policy rate still reacts to the current level of inflation, and more than one for one; that is, the Taylor-type rule is still active. In fact, in the neighborhood of the targeted steady state, there would be very little difference in choosing the linear or the nonlinear versions of the Taylor-type rule. For lower values of inflation, however, the linear Taylortype rule now extends into negative territory, violating the zero bound on nominal interest rates. Some contemporary discussion of monetary policy pines for a negative policy rate exactly as pictured here. One often hears that, given the state of today's economy, the desired policy rate would be, say, -6.0 percent, as suggested by the chart. This is nonsensical, since under current operating procedures such a policy rate is infeasible and therefore we cannot know how the economy would behave with such a policy rate. $\underline{6}$

The most disturbing part of Figure 2, however, is that the Japanese data are not part of the picture. This tempts one to argue that, because core inflation is currently below target, there is little harm in keeping the policy rate near zero and, indeed, in promising to keep the policy rate near zero in the future. There is no danger associated with such a policy according to Figure 2. There is a sort of faith that the economy will naturally return to the targeted steady state, since that is the only long-run equilibrium outcome for the economy that is part of the analysis.

\section{Stability}

There is another version of the denial view that is somewhat less extreme but nevertheless still a form of denial in the end. It is a view that I have been associated with in my own research. In this view, one accepts the zero bound on nominal interest rates and the other details of the analysis by Benhabib, Schmitt-Grohé, and Uribe. One accepts that there are two steady states. However, the steady states have stability properties associated with them in a fully dynamic analysis, and the argument is that the targeted steady state is the stable one, while the unintended, low nominal interest rate steady state is unstable. Therefore, according to this argument, one should expect to observe the economy in the neighborhood of the targeted steady state and need not worry about the unintended, low nominal interest rate steady state.

The original analysis by Benhabib, Schmitt-Grohé, and Uribe entailed much more than what I have described in Figure 1. The figure outlines just the big picture. In fact, the authors wrote down complete DSGE [dynamic stochastic general equilibrium] economies ${ }^{Z}$ and analyzed the dynamics of those systems in a series of papers. In the original analysis, the 2001 paper, they endowed both the central bank and the private sector in the model with rational expectations. They then showed that it was possible for the economy to begin in the neighborhood of the targeted steady state and follow an equilibrium path to the unintended, low nominal interest rate steady state. These dynamics in fact spiraled out from the targeted steady state.

I did not find this story very compelling, for two reasons: because the dynamics described seem unrealistic - they imply a volatile sequence of interest rates and inflation rates followed by sudden arrival at the low nominal interest rate steady state-and because they rely heavily on the foresight of the players in the economy concerning this volatile sequence.

A 2007 paper by Stefano Eusepi, now at the Federal Reserve Bank of New York, addressed some of these concerns. Eusepi accepted the nonlinear nature of Figure 1 with its two steady 
states. He also backed off the rational expectations assumption that characterized the original analysis by Benhabib, Schmitt-Grohé, and Uribe. Instead he assumed that the actors in the model might learn over time in a specific way by considering the data produced by the economy itself. 8

One key result in the Eusepi paper (2007) was the following: If the monetary authority, with its nonlinear Taylor-type policy rule, reacts to inflation one period in the past (as perhaps one might expect of many central banks), then the only possible long-run outcome for the economy is the targeted steady state. I found this comforting. It suggests that one need not worry about the unintended steady state and that exclusive focus on the targeted steady state is warranted. To be sure, a careful reading of the Eusepi paper reveals that many other dynamic paths are also possible, including some that converge to the unintended steady state. Still, one might hope that the targeted steady state is somehow the stable one-and that for this reason one can sleep better at night.

I've said this is a form of denial. First, as fascinating as they are, the results are not that clean, as many dynamics are possible depending on the details of the model. It is hard to know how these details truly map into actual economies. But more importantly, Figure 1 suggests that at least one large economy has in fact converged to the unintended steady state. The stability argument cannot cope with this datum, unless one is willing to say that conditions are subtly different in Japan compared with the United States, producing convergence to the unintended steady state in Japan but convergence to the targeted steady state in the United States. I have not seen a compelling version of this argument. I conclude that the stability argument is actually a form of denial in the end. 9

\section{The FOMC in 2003}

In Figure 1, a set of data points is circled. These data are labeled "2003-2004" and are associated with a policy rate at 1.0 percent and the inflation rate between 1.0 and 1.5 percent. This episode was the last time the FOMC worried about a possible bout of deflation. While core inflation did move to a low level during this period-not quite as low as the current level-inflation moved higher later and interest rates were increased. This episode surely provides comfort for those who think the Japanese-style outcome is unlikely. It suggests that the economy will ultimately return to the neighborhood of the targeted steady state, perhaps even indicating that the stability story is the right one after all. The 2003 experience did not involve a near-zero policy rate, however.

One description of this period is due to Daniel Thornton, an economist at the Federal Reserve Bank of St. Louis. $\underline{10}$ The Thornton analysis emphasizes (i) how the FOMC communicated during this period and (ii) how the market expectations of the longer-term inflation rate responded to the communications. At the time, some measures of inflation were hovering close to 1 percent, similar to the most recent readings for core inflation in 2010. At its May 2003 meeting, the Committee included the following press release language: "[T] he probability of an unwelcome substantial fall in inflation, though minor, exceeds that of a pickup in inflation from its already low level." At several subsequent 2003 meetings, the FOMC stated that "the risk of inflation becoming undesirably low is likely to be the predominant concern for the foreseeable future." By the beginning of 2004, inflation had picked up and FOMC references to undesirably low 
Figure 3

Inflation Expectations, Interrupted

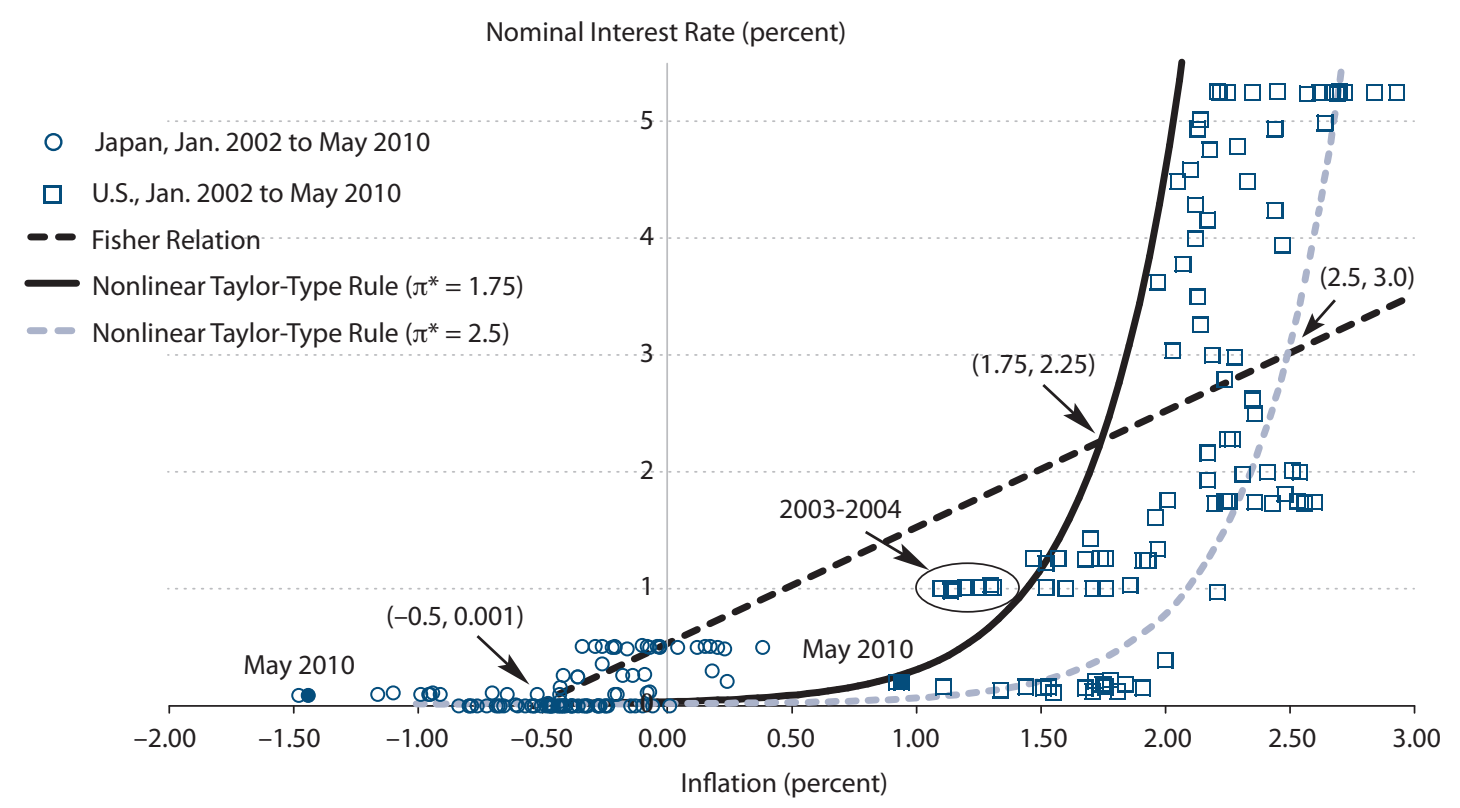

NOTE: The 2003-04 episode. Thornton $(2006,2007)$ argues that FOMC communications increased the perceived inflation target of the Committee.

inflation ceased. Thornton shows that before any of these statements were made the longer-run expected inflation rate, as measured from the 10-year Treasury inflation-indexed security spread, was 1.74 percent during the period from January 2001 through April 2003. After the statements, from January 2004 to May 2006, the longer-run inflation expectation averaged 2.5 percent. Thornton interprets the FOMC language as putting a lower bound on the Committee's implicit inflation target range. This had the effect of increasing the longer-run expected rate of inflation.

Figure 3 shows how such a change in longer-run inflation expectations might play out. Accepting the other premises of the analysis by Benhabib, Schmitt-Grohé, and Uribe, the private sector now views the central bank as taking action to contain inflation only once inflation has attained a somewhat higher level. Those in the private sector thought they understood policy as the solid black line, but after the FOMC communication, they understood policy as the dashed blue line. This alters the targeted steady-state inflation rate of the economy from 1.75 percent (the second arrow from the right in Figure 3 ) to 2.5 percent (rightmost arrow).

It is not immediately obvious from Figure 3 why this should have a desirable impact on whether the economy ultimately returns to the neighborhood of the targeted steady state or converges to the unintended, low nominal interest rate steady state. Credibly raising the inflation target is actually moving the target steady-state equilibrium to the right in the diagram, farther away from the circled data from 2003 and 2004. One might think that creating more distance from the current position to the desired outcome would not be helpful. 


\section{Figure 4}

\section{Discontinuity}



NOTE: The discontinuous Taylor-type policy rule looks unusual but eliminates the unintended steady state.

In the event, all worked out well, at least with respect to avoiding the unintended steady state. $\stackrel{11}{ }$ Inflation did pick up, the policy rate was increased, and the threat of a Japanese-style deflationary outcome was forgotten, at least temporarily. Was this a brilliant maneuver, or did the economic news simply support higher inflation expectations during this period?

\section{Discontinuity}

If the problem is the existence of a second, unintended steady state-and this is partly caused by the choice of a policy rule that is controlled by policymakers-why not just choose a different policy rule? This can, in fact, be done and was discussed by Benhabib, Schmitt-Grohé, and Uribe in their original paper. Furthermore, some parts of the current policy discussion have exactly this flavor.

The problem illustrated in Figure 1 is precisely that the two lines, one describing policy and one describing private sector behavior, cross in two places. But the policy line can be altered by policymakers. A simple version is illustrated in Figure 4. Here, the nonlinear Taylor-type policy rule is followed so long as inflation remains above 50 basis points. For inflation lower than that level, the policy rate is simply set to 1.5 percent and left there. This creates the black bar in Figure 4 between an inflation rate of -1.0 percent (or lower) and 0.5 percent. The policy would be that, for very low levels of inflation, the policy rate is set somewhat higher than zero, but still 
at a very accommodative level. After all, short-term nominal interest rates at 1.5 percent would still be considered aggressively easy policy in nearly all circumstances.

Of course, this policy looks unusual and perhaps few would advocate it, but again we are trying to avoid all those circles down there in the southwest portion of the diagram. The discontinuous policy has the great advantage that it is a very simple way to ensure that the unintended, low nominal interest rate steady state no longer exists. The only point in the diagram where the Fisher relation and the policy rule can be in harmony is the targeted equilibrium. This would remove the unintended steady state as a focal point for the economy. $\underline{12}, \underline{13}$

Some of the current policy discussion has included an approach of this type, although not exactly in this context. The FOMC's near-zero interest rate policy and the associated "extended period" language have caused many to worry that the Committee is fostering the creation of new, bubble-like phenomena in the economy that will eventually prove counterproductive. One antidote to this worry may be to increase the policy rate somewhat, while still keeping the rate at a historically low level, and then to pause at that level. $\underline{14}$ That policy would have a similar flavor to the one suggested in Figure 4, although for a different purpose.

\section{Traditional Policy}

According to the Bank of England, $\underline{15}$ for 314 years the policy rate was never allowed to fall below 2.0 percent. During more than three centuries the economy was subject to large shocks, wars, financial crises, and the Great Depression-yet 2.0 percent was the policy rate floor until very recently. A version of this policy is displayed in Figure 5. This policy rule does not eliminate the unintended steady state; it simply moves it to be associated with a higher level of inflation. In the figure, this point occurs at an interest rate of 2.0 percent and an inflation rate of 1.5 percent (the center arrow in the figure). This policy seems very reasonable in some ways. To the extent that one of the main purposes of the interest rate policy is to keep inflation low and stable, this policy creates two steady states, but the policymaker may be more or less indifferent between the two outcomes. Then one has to worry much less about the possibility of becoming permanently trapped in an unintended, deflationary steady state. This policy prevents the onset of interest rates that are "too low."

The idea that policymakers might be more or less indifferent between the two steady states brings up an important question about the original analysis by Benhabib, Schmitt-Grohé, and Uribe. Why should one steady-state equilibrium be preferred over the other? This question has some academic standing - there is a long literature on the optimal long-run rate of inflation, and lower is usually better. In the conventional policy discussion, however, the targeted steady state is definitely preferred. Perhaps the most important consideration is that, in the unintended steady state, the policymaker loses all ability to respond to incoming shocks by adjusting interest rates-ordinary stabilization policy is lost, possibly for quite a long time. In addition, the conventional wisdom is that Japan has suffered through a "lost decade" partially attributable to the fact that the economy has been stuck in the deflationary, low nominal interest rate steady state illustrated in Figure 1. To the extent that is true, the United States and Europe can hardly afford to join Japan in the quagmire. Most of the arguments I know of concerning the low nominal interest rate steady state center on the idea that deflation, even mild deflation, is undesirable. It 


\section{Figure 5}

\section{Traditional Policy}

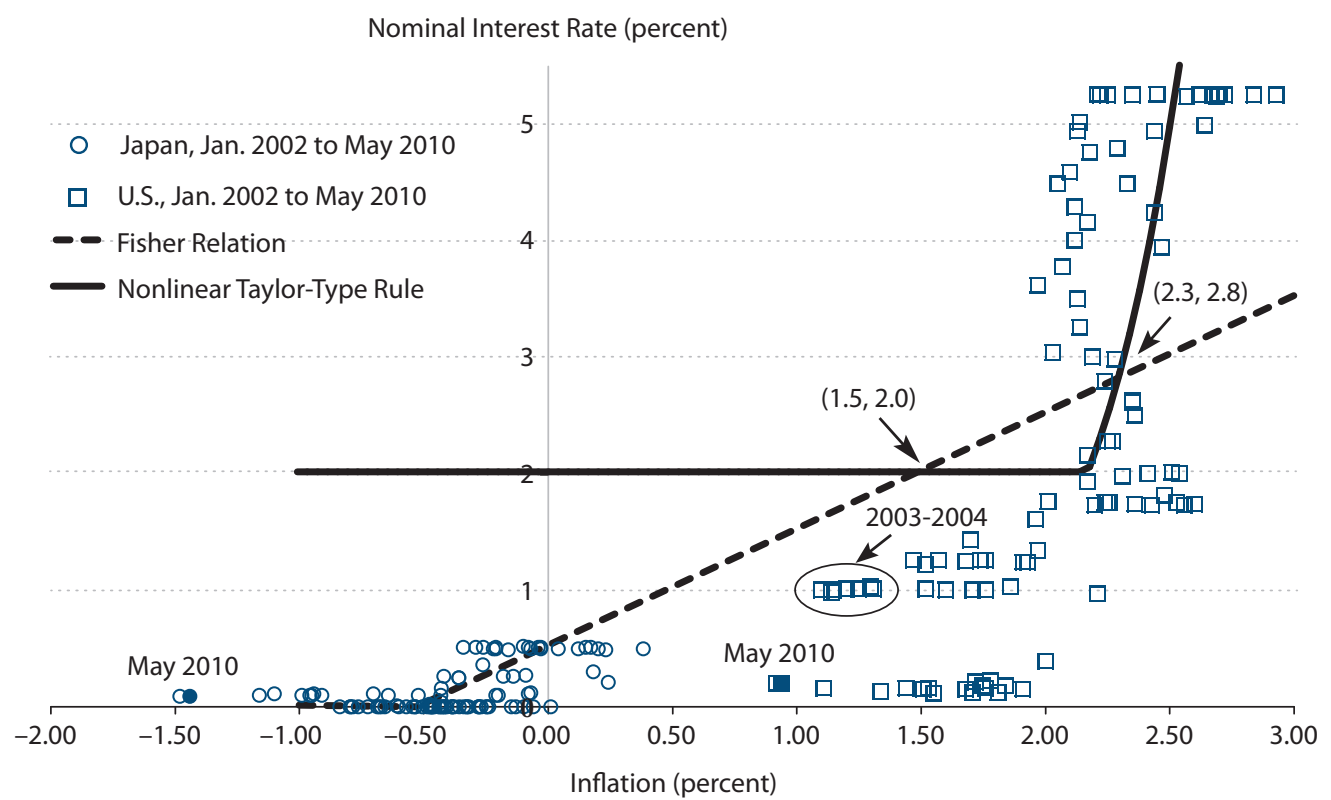

is widely perceived that problems in the U.S. financial system are at the core of the current crisis. Given that many financial contracts (and, in particular, mortgages) are stated in nominal terms and given that these contracts were written in the past (under the expectation of a stable inflation around 2.0 percent), it is conceivable to think that deflation could hurt the financial system and hamper U.S. growth. $\underline{16}$

If we suppose that deflation is the main problem, then this could likely be avoided by simply not adopting a rule that calls for very low-near-zero-interest rates. Instead, the rule could call for rates to bottom out at a level somewhat higher than zero, as the traditional policy rule does. Of course, a policy rule like the one depicted in Figure 5 does not allow as much policy accommodation in the face of shocks to the economy at the margin. But is it worth risking a "lost decade" to get the extra bit of accommodation?

\section{Fiscal Intervention Given the Situation in Europe}

In the academic literature following the 2001 publication of the perils paper, some attempt was made to provide policy advice on how to avoid the unintended steady state of Figure 1. $\underline{17}$ This advice was given in the context of trying to preserve the desirable qualities of the Taylor-type interest rate rule in the neighborhood of the targeted steady state. That is, even though interest rate rules are the problem here, the advice is given in the context of those rules-as opposed to simply abandoning them altogether.

The advice has a certain structure. It involves not changes in the way monetary policy is implemented, but changes in the fiscal stance of the government. By itself, this makes the prac- 
ticality of the solution much more questionable. But it gets worse. The proposal is for the government to embark on an aggressive fiscal expansion should the economy become enmeshed in a low nominal interest rate equilibrium. The fiscal expansion has the property that total government liabilities - money plus government debt-grow at a sufficiently fast rate. Inside the model, such a fiscal expansion eliminates the unintended steady state as an equilibrium outcome. By this roundabout method, then, the only remaining longer-run outcome for the economy is to remain in the neighborhood of the targeted steady state.

The described solution has the following flavor: The government threatens to behave unreasonably if the private sector holds expectations (such as expectations of very low inflation) that the government does not desire. This threat, if it is credible, eliminates the undesirable equilibrium. Some authors have criticized this type of solution to problems with multiple equilibria as "unsophisticated implementation." $\underline{18}$

Today, especially considering the ongoing European sovereign debt crisis, these proposed solutions strike me as wildly at odds with the realities of the global economy. The proposal might work in a model setting, but the practicalities of getting a government to essentially threaten insolvency - and be believed - seem to rely far too heavily on the rational expectations of the private sector. $\frac{19}{}$ Furthermore, governments that attempt such a policy in reality are surely playing with fire. The history of economic performance for nations actually teetering on the brink of insolvency is terrible. This does not seem like a good tool to use to combat the possibility of a low nominal interest rate steady state.

Beyond these considerations, it is questionable at this point whether such a policy actually works. Japan, our leading example in this story, has in fact embarked on an aggressive fiscal expansion, and the debt-to-GDP ratio there is now approaching 200 percent. Still, there does not appear to be any sign that their economy is about to leave the low nominal interest rate steady state, and now policymakers are worried enough about the international reaction to their situation that fiscal retrenchment is being seriously debated.

\section{Quantitative Easing}

The quantitative easing policy undertaken by the FOMC in 2009 has generally been regarded as successful in the sense that longer-term interest rates fell following the announcement and implementation of the program. $\underline{20}$ Similar assessments apply to the Bank of England's quantitative easing policy. For the United Kingdom in particular, both expected inflation and actual inflation have remained higher to date, and for that reason the United Kingdom seems less threatened by a deflationary trap. The U.K. quantitative easing program has a more state-contingent character than the U.S. program. The U.S. approach was to simply announce a large amount of purchases but not adjust the amounts or pace of purchases according to changing assessments of macroeconomic prospects.

The quantitative easing program, to the extent it involves buying longer-dated government debt, has often been described as "monetizing the debt." This is widely considered to be inflationary, and so inflation expectations are sensitive to such purchases. In the United Kingdom, all the purchases were of gilts (Treasury debt). In the United States, most of the purchases were of agency-Fannie Mae and Freddie Mac-mortgage-backed securities, newly issued in 2009. It 
has been harder to judge the inflationary effects of these purchases, and so perhaps the effects on inflation expectations and hence actual inflation have been somewhat less reliable in the United States than in the United Kingdom.

The experience in the United Kingdom seems to suggest that appropriately state-contingent purchases of Treasury securities are a good tool to use when inflation and inflation expectations are "too low." Not that one would want to overdo it, mind you, as such measures should only be undertaken in an effort to move inflation closer to target. One very important consideration is the extent to which such purchases are perceived by the private sector as temporary or permanent. We can double the monetary base one day and return to the previous level the next day, and we should not expect such movements to have important implications for the price level in the economy. Base money can be removed from the banking system as easily as it can be added, so private sector expectations may remain unmoved by even large additions of base money to the banking system. $\stackrel{21}{ }$ In the Japanese quantitative easing program, beginning in 2001, the BOJ was unable to gain credibility for the idea that they were prepared to leave the balance sheet expansion in place until policy objectives were met. And in the end, the $\mathrm{BOJ}$ in fact did withdraw the program without having successfully pushed inflation and inflation expectations higher, validating the private sector expectation. The United States and the United Kingdom have enjoyed more success, perhaps because private sector actors are more enamored with the idea that the FOMC and the U.K.'s Monetary Policy Committee will do "whatever it takes" to avoid particularly unpleasant outcomes for the economy.

\section{CONCLUSION}

The global economy continues to recover from the very sharp recession of 2008 and 2009. During this recovery, the U.S. economy is susceptible to negative shocks that may dampen inflation expectations. This could push the economy into an unintended, low nominal interest rate steady state. Escape from such an outcome is problematic. Of course, we can hope that we do not encounter such shocks and that further recovery turns out to be robust-but hope is not a strategy. The United States is closer to a Japanese-style outcome today than at any time in recent history.

In part, this uncomfortably close circumstance is due to the interest rate policy now being pursued by the FOMC. That policy is to keep the current policy rate close to zero, but in addition to promise to maintain the near-zero interest rate policy for an "extended period." But it is even more than that: The reaction to a negative shock in the current environment is to extend the extended period even further, delaying the day of normalization of the policy rate farther into the future. This certainly seems to be the implication from recent events. When the European sovereign debt crisis rattled global financial markets during the spring of 2010, it was a negative shock to the global economy and the private sector perception was certainly that this would delay the date of U.S. policy rate normalization. One might think that is a more inflationary policy, but TIPS [Treasury inflation-protected securities]-based measures of inflation expectations over 5 and 10 years fell about 50 basis points. 
Promising to remain at zero for a long time is a double-edged sword. The policy is consistent with the idea that inflation and inflation expectations should rise in response to the promise and that this will eventually lead the economy back toward the targeted equilibrium of Figure 1. But the policy is also consistent with the idea that inflation and inflation expectations will instead fall and that the economy will settle in the neighborhood of the unintended steady state, as Japan has in recent years. $\underline{22}$

To avoid this outcome for the United States, policymakers can react differently to negative shocks going forward. Under current policy in the United States, the reaction to a negative shock is perceived to be a promise to stay low for longer, which may be counterproductive because it may encourage a permanent, low nominal interest rate outcome. A better policy response to a negative shock is to expand the quantitative easing program through the purchase of Treasury securities.

\section{NOTES}

1 See Benhabib, Schmitt-Grohé, and Uribe (2001).

$\underline{2}$ This is just for purposes of discussion-much of the formal analysis to which I refer later in the paper has stochastic features that would allow the real rate to fluctuate over time. Generally speaking, short-term, real rates of return on safe assets in the United States have been very low during the postwar era.

$\underline{3}$ Steady states are considered focal points for the economy in macroeconomic theories-the economy "orbits" about the steady state in response to shocks.

4 This example is meant as an illustration only. The formula I used to plot the nonlinear Taylor-type policy rule is $R=A e^{B \pi}$, where $R$ is the nominal interest rate, $\pi$ is the inflation rate, and $A$ and $B$ are parameters. I set $A=0.005015$ and $B=2.75$. Taylor-type policy rules also have an output gap component, and in the literature that issue is discussed extensively. For the possibility of a second steady state, it is the inflation component that is of paramount importance.

5 I discuss the social desirability of each of the two steady states briefly in the section titled "Traditional Policy."

$\underline{6}$ Over the years, some discussion in monetary theory has contemplated currency taxes as a means of obtaining negative nominal rates, but that is a radical proposal not often part of the negative rates discussion. See Mankiw (2009). Interestingly, even negative rates would not avoid the multiple-equilibria problem—see, for instance, Schmitt-Grohé and Uribe (2009).

$\underline{7}$ That is, dynamic, stochastic, general equilibrium economies.

8 See Evans and Honkapohja (2001).

9 For an argument that, under learning, the targeted steady state is locally but not globally stable, see Evans, Guse, and Honkapohja (2008). In their paper, the downside risk is much more severe, as under learning the economy can fall into a deflationary spiral in which output contracts sharply.

10 See Thornton $(2006,2007)$.

11 Many have criticized the FOMC for allowing the target rate to remain too low for too long during this period. For a discussion, see remarks by Fed Chairman Bernanke (2010) delivered at the annual meeting of the American Economic Association.

12 The academic literature regarding the use of fiscal policy measures, as described below, has the same goal-unintended outcomes are eliminated as equilibria. But the fiscal policy route is far more convoluted.

13 Two astute reviewers-Costas Azariadis and Jess Benhabib—-both stressed that a discontinuous policy could create a pseudo steady state (at the point of discontinuity) and that the economy might then oscillate about the pseudo 
steady state instead of converging to the targeted outcome. This has not been a subject of research in this context as far as I know.

14 My colleague Thomas Hoenig (2010), president of the Federal Reserve Bank of Kansas City, has advocated such a policy. See his speech, "The High Cost of Exceptionally Low Rates."

15 For historical data since 1694 on the official Bank of England policy rate, see http://www.bankofengland.co.uk/statistics/rates/baserate.xls.

16 Some have argued that ongoing deflation in Japan is not an important contributory factor for the nation's relatively slow growth. See, for instance, Hayashi and Prescott (2002). In addition, the United States grew rapidly in the late nineteenth century despite an ongoing deflation. So, the relationship between deflation and longer-run growth is not as obvious as some make it seem. Still, the conventional wisdom is that a turn toward deflation would hamper U.S. growth.

17 See, in particular, Benhabib, Schmitt-Grohé, and Uribe (2002), Woodford (2001, 2003), and Eggertsson and Woodford (2003).

18 See Atkeson, Chari, and Kehoe (2010).

19 For a version that backs off the rational expectations assumption, but still eliminates the undesirable equilibrium, see Evans, Guse, and Honkapohja (2008).

$\underline{20}$ See, for instance, Neely (2010).

$\underline{21}$ For discussions of how forms of quantitative easing can help achieve the intended steady state, in combination with appropriate fiscal policy, see Eggertsson and Woodford (2003, pp. 194-98) and Evans and Honkapohja (2005).

$\underline{22}$ Evans and Honkapohja (2010) have made a version of this argument more formally.

\section{REFERENCES}

Atkeson, Andrew; Chari, Varadarajan and Kehoe, Patrick. "Sophisticated Monetary Policies." Quarterly Journal of Economics, February 2010, 125(1), pp. 47-89.

Benhabib, Jess; Schmitt-Grohé, Stephanie and Uribe, Martín. "The Perils of Taylor Rules." Journal of Economic Theory, January 2001, 96(1-2), pp. 40-69.

Benhabib, Jess; Schmitt-Grohé, Stephanie and Uribe, Martín. "Avoiding Liquidity Traps." Journal of Political Economy, June 2002, 110(3), pp. 535-63.

Bernanke, Ben S. "Monetary Policy and the Housing Bubble." Remarks before the Annual Meeting of the American Economic Association, Atlanta, GA, January 3, 2010; http://www.federalreserve.gov/newsevents/speech/bernanke20100103a.htm.

Eggertsson, Gauti and Woodford, Michael. "The Zero Bound on Interest Rates and Optimal Monetary Policy." Brookings Papers on Economic Activity, 2003, 1, pp. 139-211.

Eusepi, Stefano. "Learnability and Monetary Policy: A Global Perspective." Journal of Monetary Economics, May 2007, 54(4), pp. 1115-131.

Evans, George; Guse, Eran and Honkapohja, Seppo. "Liquidity Traps, Learning, and Stagnation." European Economic Review, November 2008, 52(8), pp. 1438-463.

Evans, George and Honkapohja, Seppo. Learning and Expectations in Macroeconomics. Princeton, NJ: Princeton University Press, 2001.

Evans, George and Honkapohja, Seppo. "Policy Interaction, Expectations and the Liquidity Trap." Review of Economic Dynamics, April 2005, 8(2), pp. 303-23.

Evans, George and Honkapohja, Seppo. "Expectations, Deflation Traps and Macroeconomic Policy," in David Cobham, Øyvind Eitrheim, Stefan Gerlach, and Jan F. Qvigstad, eds., Twenty Years of Inflation Targeting: Lessons Learned and Future Prospects. Chap. 11. Cambridge, UK: Cambridge University Press, 2010, pp. 232-60. 


\section{Bullard}

Hayashi, Fumio and Prescott, Edward C. "The 1990s in Japan: A Lost Decade." Review of Economic Dynamics, January 2002, 5(1): 206-35.

Hoenig, Thomas M. "The High Cost of Exceptionally Low Rates." Remarks before the Bartlesville Federal Reserve Forum, Bartlesville, OK, June 3, 2010; http://www.kcfed.org/speechbio/Hoenigpdf/Bartlesville.06.03.10.pdf.

Mankiw, N. Gregory. "It May Be Time for the Fed to Go Negative." New York Times, April 18, 2009; http://www.nytimes.com/2009/04/19/business/economy/19view.html.

Neely, Christopher J. “The Large Scale Asset Purchases Had Large International Effects.” Working Paper No. 2010-18A, Federal Reserve Bank of St. Louis, July 2010.

Schmitt-Grohé, Stephanie and Uribe, Martín. "Liquidity Traps with Global Taylor Rules." International Journal of Economic Theory, 2009, 5(1), pp. 85-106.

Thornton, Daniel L. “The Fed's Inflation Objective." Federal Reserve Bank of St. Louis Monetary Trends, July 2006; http://research.stlouisfed.org/publications/mt/20060701/cover.pdf.

Thornton, Daniel L. "The Lower and Upper Bounds of the Federal Open Market Committee's Long-Run Inflation Objective." Federal Reserve Bank of St. Louis Review, May/June 2007, 89(3), pp. 183-93; http://research.stlouisfed.org/publications/review/07/05/Thornton.pdf.

Woodford, Michael. "Fiscal Requirements for Price Stability." Journal of Money, Credit, and Banking, August 2001, 33(3), pp. 669-728.

Woodford, Michael. Interest and Prices: Foundations of a Theory of Monetary Policy. Princeton, NJ: Princeton University Press, 2003. 